\title{
Age variations of melatonin level and its hormesis; implications for AIS and osteoporosis
}

\author{
TB Grivas*1, ES Vasiliadis ${ }^{2}$, G Triantafyllopoulos ${ }^{1}$, A Kaspiris ${ }^{2}$ and \\ RG Burwell ${ }^{3}$
} \author{
Brilissia, Attica, 15235, Greece \\ Email: TB Grivas* - grivastb@vodafone.net.gr \\ * Corresponding author \\ from 6th International Conference on Conservative Management of Spinal Deformities \\ Lyon, France. 2I-23 May 2009 \\ Published: 14 December 2009 \\ Scoliosis 2009, 4(Suppl 2):O8 doi: I0.I|86/1748-7|6|-4-S2-O8
}

Address: ${ }^{1}$ Department of Trauma and Orthopaedics, "Tzanio" General Hospital - NHS, Tzani and Afendouli, 18536, Piraeus, Greece, ${ }^{2}$ Department of Trauma and Orthopaedics, "Thriasio" General Hospital - NHS, G, Gennimata Av, 19600, Magoula, Attica, Greece and 3The Centre for Spinal Studies \& Surgery, Nottingham University Hospitals Trust, Queen's Medical Centre Campus, Nottingham NG7 2UH, UK, D. Bernardou 31

This abstract is available from: http://www.scoliosisjournal.com/content/4/S2/O8

(C) 2009 Grivas et al; licensee BioMed Central Ltd.

\section{Indroduction}

Melatonin, the "light of night", is a very important hormone for the function of the human organism. Its secretion increases in early childhood. In adolescence there is a decrease of the hormone concentration. The levels continue to decline gradually during middle age. In an older population the levels of melatonin in the serum are very low. Among many other functions, melatonin is involved in human sexual maturation and then declines, affecting menses and osteogenesis.

\section{Methods and materials}

The development of menarche could be explored for evidence of hormesis. Hormesis is defined as the response of cells or organisms to an exogenous substance (e.g. a drug or toxin) or an intrinsic factor (e.g. a hormone) in which the factor induces stimulatory or beneficial effects at low doses and inhibitory or adverse effects at high doses [bimodal dose-response] or vice versa.

\section{Results}

When menarche is at about 10 years, this is the age at which AIS appears, and the circulating melatonin levels are about $120 \mathrm{pg} / \mathrm{ml}$ - positive hormesis for menses, figure 1. If there is a circulating melatonin defect, then a delay of menarche compared with the normal peers is expected, and subsequently, the female is susceptible to scoliosis. In this way, melatonin could be certainly involved in the pathogenesis of Scoliosis [1]. Around the age of 45 years when the circulating melatonin levels are about $20 \mathrm{pg} / \mathrm{ml}$ - negative hormesis for menses - (figure 1), menopause begins. As a result of the problems of osteoporosis, fractures then start [2-5].

\section{Discussion}

The bone-protecting effect of melatonin is well documented in ovariectomized rats which can depend in part on the free radical scavenging properties of melatonin. Additionally, melatonin may impair development of osteopenia associated with senescence by improving nonrapid eye movement sleep and restoring GH secretion. Whether modulation of blood levels of melatonin can be used as a novel mode of therapy for scoliosis and augmenting bone mass in diseases deserves to be studied [3]. 


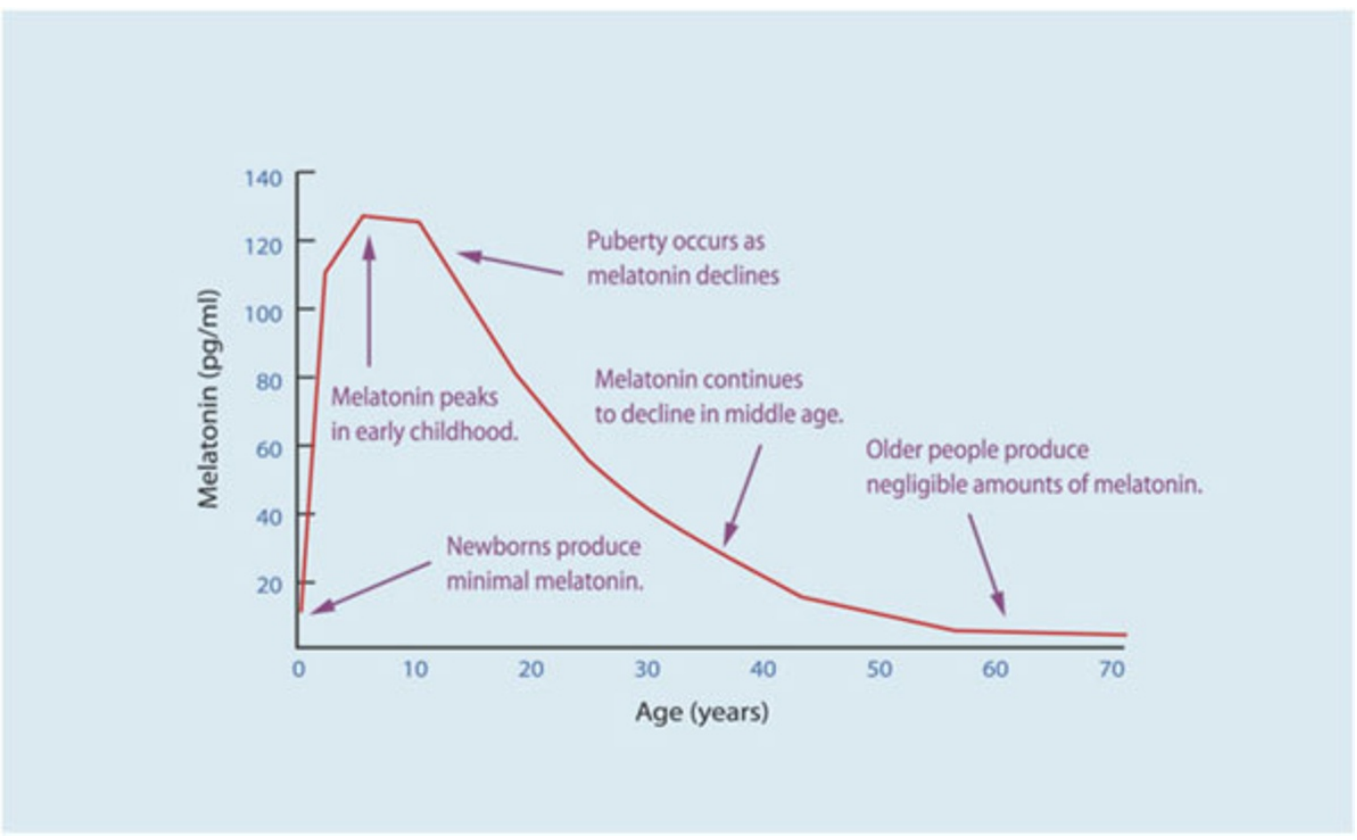

\section{Figure I}

\section{References}

I. Grivas TB, Vasiliadis E, Mouzakis V, Mihas C, Koufopoulis G: Association between adolescent idiopathic scoliosis prevalence and age at menarche in different geographic latitudes. Scoliosis 2006, I:9.

2. Feskanich D, Hankinson SE, Schernhammer ES: Nightshift and fracture risk: the Nurses' Health Study. Osteoporos Int 2008.

3. Cardinali DP, Ladizesky MG, Boggio V, Cutrera RA, Mautalen C: Melatonin effects on bone: experimental facts and clinical perspectives. J Pineal Res 2003, 34:8I-87.

4. Pandi-Perumal SR, Srinivasan VG, Maestroni GJM, Cardinali DP, Poeggeler B, Hardeland R: Melatonin. FEBS J 2006, 273:28I3-2838.

5. Witt-Enderby PA, Radio NM, Doctor JS, Davis VL: Therapeutic treatments potentially mediated by melatonin receptors: potential clinical uses in the prevention of osteoporosis, cancer and as an adjuvant therapy. J Pineal Res 2006, 4I:297-305.

Publish with Bio Med Central and every scientist can read your work free of charge

"BioMed Central will be the most significant development for disseminating the results of biomedical research in our lifetime. "

Sir Paul Nurse, Cancer Research UK

Your research papers will be:

- available free of charge to the entire biomedical community

- peer reviewed and published immediately upon acceptance

- cited in PubMed and archived on PubMed Central

- yours - you keep the copyright 